\title{
INTERVIEW WITH ALICE SCHWARZER
}

\begin{abstract}
Alice Schwarzer is the Gloria Steinem of West German second wave feminism. A reporter by training, Schwarzer studied sociology and psychology at Vincennes from 1970 to 1974 and was actively involved in the French women's movement. She first met Simone de Beauvoir in 1970. Schwarzer made herself a household name in West Germany in 1971 when she organized —on the model of French feminists-a campaign for abortion rights ("Selbstbezichigungskampagne") that used the mass magazine Der Stern and had high-profile women in the arts, politics, and culture denounce themselves as having had abortions. It effectively sparked the new West German women's movement. In 1977 Schwarzer founded Emma, the first West German feminist magazine "by women for women" for which she continues to serve as publisher and editor. The author of numerous feminist books, a sought-after speaker, and an outspoken organizer against pornography and other forms of sexual violence, Schwarzer remains controversial. The following interview presents Schwarzer's written responses to questions on the presence of Beauvoir's ideas in Schwarzer's work and her relevance to present-day feminism.
\end{abstract}

Sabine Engel: You have consistently engaged Simone de Beauvoir's work and project and were friends with her. What do you think about Simone de Beauvoir as a philosopher and a political activist, especially in relation to Le deuxième sexe?

Alice Schwarzer: In my view what's most crucial about Simone de Beauvoir is the intersection of project, life, and political engagement. With her all three aspects were intertwined until the very end, which made for the incredible precision, honesty, and radicalism of her thinking and writing. Beauvoir's philosophy is a philosophy of life; all of her thinking confronts this life. More than half a century after the publication of Le deuxième sexe, there is only one point where the New Feminism has pushed further its thinking and that regards the central role of (sexual) violence in the relations of power between men and women. During Beauvoir's time this topic seems to have been so taboo that even as fearless a thinker as she could not perceive it appropriately. But on the conflict most crucial to feminism from its beginningsequality or difference?-Beauvoir provides the most comprehensive and consistent analysis to date. Sharp-sighted, she dismantles any idealization of an alleged difference between human beings. Her 
volume's concluding chapter "Toward Liberation" brilliantly analyzes the conflict so topical for today's women: freedom or love?

Sabine Engel: Your collection of conversations with Simone de Beauvoir, published in English as Simone de Beauvoir Today: Conversations, 1972-1982 (London 1984), was important and has been widely read among women the world over. It seems as if Beauvoir there affirms a conversion: from being a philosopher who happened to be a woman she turned into someone who accepts herself as a woman who is a philosopher. One of your questions she answered quite explicitly with "I am a feminist." What do you think about that today?

Alice Schwarzer: When Simone de Beauvoir-the adult woman and companion of intellectual men-was writing Le deuxième sexe she forgot something she once had known as a girl: that freedom and femininity are incompatible. Having closely observed M. de Wendel, "so pretty and unaffected" whom she "envied" so much, the nineteenyear-old student of philosophy notes in her diary (excerpts of which have been published recently by the philosopher Margaret A. Simons) [see Simons, Beauvoir and The Second Sex 185-243]:

But I would so like to have the right me as well of being simple and very weak, of being a woman; in what a "desert world" I walk, so arid, with the only oasis my intermittent esteem for myself. ... I count on myself; I know that I can count on myself. But I would prefer to have no need to count on myself. (Beauvoir [1927])

What an extremely topical conflict! Beauvoir wrote Le deuxième sexe in the immediate post-war period precisely during her passionate love affair with Nelson Algren - but she did so as an emancipated woman working in profound isolation. There was no women's movement; there wasn't even a public feminist discourse then. The first women's movement and its foremothers once again had been erased from memory and Second Wave feminism would not arrive until twenty years later. When Beauvoir single-handedly broke that silence and repostulated feminism, her progressive fellow companions by and large reacted with scorn and ridicule. But when the new women's movement arrived, to a not inconsiderable degree owing its consciousness to having read her, Beauvoir immediately knew that she was part of it. In 1970 when the Mouvement de liberation des femmes formed in Paris, Simone de Beauvoir immediately and without reservations responded to the very first inquiry by a mere handful of feminist activists"would you like to join us?"-with an enthusiastic "Yes!" For Beauvoir, the intellectual, to engage in concrete feminist struggle was 
natural the minute this structure existed. Yet for her to "accept herself as a woman"--for that a Simone de Beauvoir did not need a women's movement: from the start she knew that she was one and clearly understood the conflicts it creates in a world governed by men. Her early novels and the recently discovered diary of the nineteen-year-old both demonstrate that.

Sabine Engel: Over the past thirty years you have published important books that directly or indirectly refer to Le deuxième sexe. I would like to mention only a few of them here: Der "kleine Unterschied" und seine grossen Folgen, first published in 1975 and quickly translated into twelve languages, including French and Spanish, has just been published in another, enlarged edition. Your volume Simone de Beauvoir, Rebellin und Wegbereiterin appeared in 1999. That same year you organized a three-day conference in Cologne that is documented in Man wird nicht als Frau geboren (2000). Finally, this past year you submitted Der grosse Unterschied, whose subtitle articulates a special agenda: Gegen die Spaltung von Menschen in Maenner und Frauen. Could you talk about that?

Alice Schwarzer: My work stands in the tradition of radical feminists (that's what the anti-biologistic feminists of the past chose to call themselves in Germany) and universalist feminists (which is what they call themselves today the world over) and thus in the tradition also of the most significant thinker of equality feminism, namely Simone de Beauvoir. I simply fail to grasp why Simone de Beauvoir's workwhich for us new feminists represented a flaming light in the darkness-is being dismantled and is even slipping from memory today. We are thereby denying our own history and depriving ourselves of existential knowledge and the possibility to think further.

Sabine Engel: What do you think about the reception of the fundamental claims and hypotheses of Le deuxième sexe in Germany?

Alice Schwarzer: In Germany the reception of Beauvoir is similar to what it is all over the Western world: she is a classic every woman and man claim to know-but in fact the smallest number has actually read her. Otherwise people couldn't spread so much nonsense about her. Moreover, Simone de Beauvoir understandably is one of the main enemies of all proponents, male or female, of difference, who-which is particularly annoying-don't say where exactly they disagree with her arguments but instead content themselves with personal defamation. 
Sabine Engel: Finally a question that probably has resonated some in your responses but that I'd like you to address explicitly. How has Simone de Beauvoir affected your life as a woman and a critical thinker?

Alice Schwarzer: I had the good fortune of collaborating with Simone de Beauvoir as a political activist and of being a personal friend of hers for fifteen years. Her consistency combined with her love for argument, her modesty combined with the knowledge that her work was valuable, her joy for life combined with the refusal to ignore the suffering of others, all that strengthened my resolve to try a similar path. At the time it was more of an unconscious choice, but in retrospect I see very clearly that very encouraging influence of hers. 